\title{
IDENTIFIKASI DAN PENENTUAN KADAR RESIDU INSEKTISIDA PADA KUBIS DAN TOMAT DI MODOINDING DAN RURUKAN
}

\author{
INDENTIFICATION AND DETERMINATION OF INSECTICIDE RESIDUE LEVELS ON \\ CABBAGES AND TOMATOES IN MODOINDING AND RURUKAN
}

\author{
Yoakhim. Y. E. Oessoe
}

Dosen Fakultas Pertanian, Universitas Sam Ratulangi Manado, 95115

\begin{abstract}
This research aims to study 1) Maternal effect on the inheritance of yield components of Manado Yellow Use of Insecticides is one way that is very often made vegetable farmersto cope with pest and plant diseases. However, the use of insecticides may give negative effects for consumers of food containing residues of these poisons.Methodology of research is survey and laboratory. Collecting data in the survey was an interview of 20 vegetable farmers, each 10 from Modoinding and 10 from Rurukan that determined purposively. Laboratory data obtainedwith the ways to identify residues in the cabbage and tomatoes from Modoinding and Rurukan, using Gas Chromatography (GC) according to the analysis method of Pusat Pengujian Obat dan Makanan.Vegetable farmers in Modoinding and Rurukan often apply the insecticide organophospate and pyretroid on cabbage and tomato plants. The residues level in ccabbage and tomato from Modoinding and Rurukan far exceed the value of Acceptable Daily Intake of profonefos allowed.
\end{abstract}

Keywords: identification, Residue, Insecticide, profenofos

\begin{abstract}
ABSTRAK
Penggunaan insektisida merupakan salah satu cara yang sangat sering dilakukan petani sayuran untuk mengulangi hama dan penyakit tanaman. Namun penggunaan insektisida dapat memberikan efek negatif bagi konsumen bahan pangan yang mengandung residu yang bersifat racun tersebut. Metode penelitian yakni metode survey dan laboratorium. Pengumpulan data survei secara wawancara pada 20 petani sayur, masing-masing 10 dari Modoinding dan 10 dari Rurukan yang ditentukan secara purposive. Data laboratorium didapatkan dengan cara mengidentifikasi residu pada kubis dan tomat dengan menggunakan Gas Chromatography (GC), sesuai metode analisa Pusat Pengujian Obat dan Makanan. Petani sayur di Modoinding dan Rurukan sering mengaplikasikan insektisida golongan organofosfat dan piretroid. Kadar residu profenofos pada kubis dan tomat di Modoinding dan Rurukan jauh melebihi nilai Acceptable Daily Intake dari profenofos yang diizinkan.

Kata kunci : identifikasi, Residu, Insektisida, profenofos
\end{abstract}




\section{PENDAHULUAN}

Kebutuhan konsumen pangan di Indonesia akan sayuran, terus meningkat dari waktu ke waktu seiring meningkatnya jumlah penduduk. Meningkatnya kebutuhan sayuranditingkat konsumen, perlu diimbangi dengan usaha meningkatkan produksi sayuran.

Salah satu aspek yang sering mendapat perhatian dalam menunjang terwujudnya produksi sayuran yang baik secara kuantitas dan kualitas , adalah upaya pengendalian hama dan penyakit sayuran. Di Sulawesi Utara saat ini penggunaan pestisida masih sering dilakukan petani untuk mengendalikan hama dan penyakit pada tanaman sayuran.

Pestisida (Inggris : pesticide) secara harfiah berarti pembunuh hama. Selain itu, menurut The united States Enviromental Pesticide Control Act, pestisida adalah semua zat atau campuran zat yang khusus digunakan untuk mengendalikan, mencegah atau menangkis gangguan serangga, binatang pengerat, nematode, gulma, virus, bakteri, jasad renik yang dianggap hama, kecuali virus , bakteri atau jasad renik yang terdapat dalam tubuh manusia dan binatang (Djojosumarto, 2010).

Pestisida dapat diklasifikasikan menjadi bermacam -macam dengan berdasarkan fungsi dan asal kata seperti : Insektisida, herbisida, fungisida, nematisida, rodentisida, bakterisida, akarisida, algisida,mitisida, molluskisida, avisida, silmisida, piscisida, ovisida (Sudarmo, 1999).

Penggunaan pestisida meskipun dapat membantu meningkatkan produksi tanaman, tetapi ditinjau dari aspek keamanan pangan (Food Safety), merupakan bahaya bagi konsumen. Hal ini disebabkan terdapatnya residu pestisida pada komoditi yang dihasilkan.

Residu pestisida yang terdapat pada komoditi hasil pertanian seperti sayuran, sangat berbahaya bagi manusia. Dari beberapa hasil penelitian ada indikasibahwa residu pestisida dapat mendorong terbentuknya jaringan kanker. Menurut WHO, sekitar 20.000 orang per tahun meninggal akibat keracunan pestisida dan sekitar 5000 - 10000 orang per tahunmengalami dampak yang sangat fatal sepertikanker, cacat tubuh, kemandulan dan penyakit liver ( Pandit, 2006). Residu pestisida pada komoditi hasil pertanian, terkadang melampaui batas dosis yang dizinkan.

Residu pestisida dalam bahanpangan perlu diwaspadai walaupun kadarnya mungkin tergolong kecil. Hal ini disebabkan residu pestisida yang masukterus menerus ke dalam tubuh , pada akhirnya akan menimbulkan efek keracunan yang tidak diinginkan.

Tingkat keracunan pestisida dapat dibedakan menjadi : 1) Acute poisoning,yaitu keracunan yang terjadi akibat masuknya sejumlah besar pestisida sekaligus ke dalam tubuh, 2) sub-acute poisoning adalah keracuanan yang disebabkan oleh sejumlah kecil pestisida yang masuk ke dalam tubuh tetapi terjadi berulang-ulang, 3) chronic poisoning adalah keracunan akibat masuknya sejumlah kecil pestisida dalam waktu yang lama dan pestisida mempunyai kecenderungan terakumulasi dalam tubuh (Pandit, 2006).

Residu pestisida tidak hanya ditemukan pada bahan pangan tetapi sering terakumulasi juga pada berbagai komponen lingkungan yang lain, seperti : Udara, air dan tanah pertanian. Terakumulasinya residu pestisida pada komponen lingkungan mengakibatkan pencemaran lingkungan yang membahayakan mahluk hidup.

Berbagai jenis sayuran tumbuh dengan baik pada hamper seluruh daerah dilndonesia, termasuk diantaranya Sulawesi Utara. Rurukan dan Modoinding adalah dua wilayah sentra produksi sayuran di Sulawesi Utara. Petani di kedua wilayah ini cukup banya membudidayakan kubis dan tomat. Petani di kedua wilayah ini juga menggunakan pestisida dalam uapaya mengendaliakan oraganisme pengganggu tumbuhan

Salah satu kelompok pestisida yang digunakan petani di daerah ini adalah insektisida. Insektisida digunakan untuk membunuh atau mengendalikan serangan serangga pada tanaman. Insektisida berasal dari kata Latin insectum artinya serangga dan cidae berarti membunuh. Insektisida merupakan salah satu dari bermacam- macam pestisida yang dapat 
membunuh hama berupa serangga ( Hadi 1981). Djojosumarto, 2000) mengelompokkan insektisida secara kimia dalam beberapa kelompok, yaitu : tiosoanat, dinitrofenol, fluoroasetat, insektisida anorganik dan fumigant, insektisida botanis, hidrokarbon berkhlor, organofosfat, karbamat, piretroid, mikroorganisme, kelompok urea.

Penelitian ini bertujuan mendata jenis insektisida yang digunakan petani sayur di Rurukan dan Modoinding, Mengidentifikasi dan mengukur residu Insektisida pada kubis sertamengidentifikasi residu insektisida dalam tanah (lahan pertanian) di Modoinding dan Rurukan.

\section{METODE PENELITIAN}

Penelitian ini di lakukan selama dua bulan mulai Nopember s/d Desember di Laboratorium Balai Besar Pengawasan Obat dan Makanan (BBPOM) di Manado.

Bahan yang digunakan adalah kubis (Brassica oleracea, L) dan tomat (Lycopersicum esculentum Mill) dari Modoinding dan Rurukanserta bahan atau pereaksi untuk uji identifikasi dan penetapan kadar pestisida yaitu : larutan heksan, aseton, aquadest, ammonium klorida, natrium sulfat anhidrat,wol kaca, insektisida golongan organofosfat yang terdiri dari profenofos dan metidation serta insektisida golongan piretroid yang terdirui dari : deltametrin, sipermetrin, abamektin dan lamda sihalotrin.

Alat yang digunakan dalampenelitian ini adalah : pisau, tropol, kantong plastik, coll box,timbangan analitik, blender, corong, Erlenmeyer, rotary vakum, ayakan, shaker, kolom florisil, labu pemisah, labu ukur,kromatografi gas merk Shimadzu tipe 16A menggunakan detector Electron Capture Detector (ECD) dan syringe untuk injeksi.

Penelitian ini di laksanakan dalam 2 (dua) tahap, yakni :Penelitian pendahuluan : Dilakukan dalam bentuk survey ditingkat petanisayur, untuk mendata semua jenis insektisida yang sering diaplikasikan pada kubis dan tomat di Modoinding dan Rurukan. Data dikumpulkan berdasarkan informasi dari 10 (sepuluh) orang responden yaitu petani sayurdi Modoinding dan 10 (sepuluh) orang petani sayur diRurukanyang dipilih secara purposive. Masingmasing petani diwawncarai secara singkat sesuai kuisioner.Penelitian lanjutan :Tahap selanjutnya adalah melakukan uji identifikasi.sekaligus penetapan kadar residu insektisida pada komoditi kubis dan tomat serta sedimen tanh yang berasal dari Modoinding dan Rurukan. Tahappenelitian ini diawali dengan pengambilan sampel sayuran kubisdan tomat serta sampel berupa sedimen tanah.Pengujian laboratorium menggunakan beberapa metode yaitu : Metode Identifikasi dan Penetapan Kadar Residu Insektisida Golongan Organofosfat pada Kubis dan Tomat (MAPPOM,1990); Metode Identifikasi dan penetapan kadar residu insektisida golongan piretroid pada kubis dan tomat (Komisi Pestisida, 1997); Metode Identifikasi dan penetapan kadar residu insektisida golongan organofosfat dan piretroid pada tanah (AOAC,2005).Data survei penggunaan insektisidan di Tingkat Petani. Survei di tingkat tentang jenis insektisida yang sering diaplikasikan pada tanaman kubis dan tomat di Modoinding dan Rurukan, nampak pada Tabel 1 dan 2 dibawah ini : 


\section{HASIL DAN PEMBAHASAN}

Tabel 1. Jenis Insektisida Yang Sering Diaplikasikan Pada Kubis dan Tomat di Modoinding

\begin{tabular}{lll}
\hline $\begin{array}{c}\text { Jenis } \\
\text { Tanaman }\end{array}$ & \multicolumn{1}{c}{ Nama Dagang } & \multicolumn{1}{c}{ Jenis Insektisida Yang Digunakan } \\
Nama Bahan Aktif
\end{tabular}

Tabel 2. Jenis Insektisida Yang Seeing Diaplikasikan Pada Kubis dan Tomat Di Rurukan

\begin{tabular}{|c|c|c|}
\hline Jenis & \multicolumn{2}{|c|}{ Jenis Insektisida Yang Digunakan } \\
\hline Tanaman & Nama Dagang & Nama Bahan Aktif \\
\hline Kubis & $\begin{array}{l}\text { Decis } 2,5 \mathrm{C} \\
\text { fastac } 15 \mathrm{EC} \\
\text { Turex WP } \\
\text { Curacron } 500 \mathrm{EC}\end{array}$ & $\begin{array}{l}\text { Deltametrin } \\
\text { Alfametrin } \\
\text { Delta Endotoksin pada Bacillus thuringiensis } \\
\text { Profenofos }\end{array}$ \\
\hline Tomat & $\begin{array}{l}\text { Curacron } 500 \text { EC } \\
\text { Fastac } 15 \text { EC } \\
\text { Decis } 2,5 \text { C } \\
\text { Agrimec } 18 \text { EC } \\
\text { Turex WP Supracide } \\
25 \text { WP }\end{array}$ & $\begin{array}{l}\text { Profenofos } \\
\text { Alfametrin } \\
\text { Deltametrin } \\
\text { Abamektin } \\
\text { Delta Endotoksin pada Bacillus thuringiensis } \\
\text { Metidation }\end{array}$ \\
\hline
\end{tabular}

Dari hasil survei di tingkat petani pada dua wilayah sentra produksi sayur- sayuran di Sulawesi Utara yaitu Modoinding dan Rurukan, yang ditampilkan pada table 1 dan 2, terdapat persamaan dan perbedaan dari jenis insektisida yang digunakan. Insektisida dengan nama dagang Matador $25 \mathrm{CS}$, Arivo 30 EC, meteor 25 EC dan Sidametrin 50 EC yang masing- masing berbahanaktif : lamda siholotrin dan sipermetrin, hanyadiperoleh dari data survey petani di Modoinding. Disamping itu, insektisida dengan nama dagang agrimec $18 \mathrm{EC}$ dan supracide 25 WP yang masing-masing berbahan aktif abamektin dan metidation hanya diperoleh dari hasil survei petani di Rurukan. Jenis insektisida Curacron 500 EC (profenofos), decis 2,5 C (deltametrin), Fastac 15 EC (alfametrin) dan turexWP (Delta Endotoksin pada Bacillus thuringiensis semuanya diaplikasikan oleh petani di Modoinding dan Rurukan. Berdasarkan sebagian besari jenis insektisida yang diaplikasikan oleh Petani di Modoinding dan Rurukan termasuk dalam golongan insektisida organofosfat dan piretroid. Selain itu ada juga jenis insektisida lain yaitu golongan insketisida mikroba dengan nama dagang Turex WP ( dellta endotoksin pada Bacillus thuringiensis 
B. indetifikasi dan Penetapan Kadar Residu Insektisida Pada Kubis dan Tomat Berdasarkan data hasil Survey yang ada, maka untuk mengetahui lebih jelas tentang keberadaan residu insektsida pada kubis dan tomat telah dilakukan uji identifikasi dan penetapan kadar residu. Hasil uji identifikasi dan penetapan kadar residu, terlihat pada tabel 3 dan 4

Tabel 3. Kadar Residu Insektisida Pada Kubis dan Tomat di Modoinding

\begin{tabular}{lllccc}
\hline $\begin{array}{c}\text { Jenis } \\
\text { Tanaman }\end{array}$ & Jenis Insektisida & $\begin{array}{l}\text { Golongan } \\
\text { Insektisida }\end{array}$ & \multicolumn{2}{c}{$\begin{array}{c}\text { Kadar Residu Insektisida } \\
(\mathrm{ppm})\end{array}$} \\
\hline \multirow{3}{*}{ Kubis } & Alfametrin & Piretroid & $\mathrm{t}$ & $\mathrm{Il}$ & $\mathrm{III}$ \\
& Profenofos & Organofosfat & 7,0442 & $\mathrm{ttd}$ & $\mathrm{ttd}$ \\
& Sipermetrin & Piretroid & $\mathrm{ttd}$ & $\mathrm{ttd}$ & $\mathrm{ttd}$ \\
\multirow{4}{*}{ Tomat } & Alfametrin & Piretroid & $\mathrm{ttd}$ & $\mathrm{ttd}$ & $\mathrm{ttd}$ \\
& Deltametrin & Piretroid & $\mathrm{ttd}$ & $\mathrm{ttd}$ & $\mathrm{ttd}$ \\
& Profenofos & Organofosfat & 7,1372 & 6,9929 & $\mathrm{ttd}$ \\
& Lamda Sihalotrin & Piretroid & $\mathrm{ttd}$ & $\mathrm{ttd}$ & $\mathrm{ttd}$ \\
\hline
\end{tabular}

Tabel 4 di bawah ini menunjukkan kadar residu insektida profenofos pada kubis dan tomat di Rurukan.

\begin{tabular}{|c|c|c|c|c|c|}
\hline \multirow[t]{2}{*}{$\begin{array}{l}\text { Jenis } \\
\text { Tanaman }\end{array}$} & \multirow[t]{2}{*}{$\begin{array}{l}\text { Jenis } \\
\text { Insektisida }\end{array}$} & \multirow[t]{2}{*}{$\begin{array}{l}\text { Golongan } \\
\text { Insektisida }\end{array}$} & \multicolumn{3}{|c|}{$\begin{array}{c}\text { Kadar Residu Insektisida } \\
\text { (ppm) }\end{array}$} \\
\hline & & & 1 & II & III \\
\hline \multirow[t]{3}{*}{ Kubis } & Alfametrin & Piretroid & $\mathrm{ttd}$ & ttd & ttd \\
\hline & Deltametrin & Organofosfat & $\mathrm{ttd}$ & ttd & ttd \\
\hline & Profenofos & Piretroid & $\mathrm{ttd}$ & 8,5573 & 9,9672 \\
\hline \multirow[t]{5}{*}{ Tomat } & Abamektin & Piretroid & $\mathrm{ttd}$ & ttd & $\mathrm{ttd}$ \\
\hline & Alfametrin & Piretroid & $\mathrm{ttd}$ & $\mathrm{ttd}$ & $\mathrm{ttd}$ \\
\hline & Deltametrin & Piretroid & ttd & ttd & ttd \\
\hline & Metidation & Piretroid & ttd & $\mathrm{ttd}$ & $\mathrm{ttd}$ \\
\hline & Profenofos & Organofosfat & 6,8721 & $\mathrm{ttd}$ & 6,9260 \\
\hline
\end{tabular}

Data tabel 3 menjelaskan bahwakadar residu insektisida profenofos pada kubis dari wilayah Modoinding, adalah tidak terdeteksi (ttd) dan 7,0442 ppm.Kadar residu insektisida profenofos pada tomat, berkisar antara todak terdeteksi (ttd) sampai 7,1372. Perbedaan kadar residu yang ditemukan pada kubis dan tomatuntuk wilayah Modoinding, menunjukkan nilai yang sangat kecil. Hal ini disebabkan frekwensi aplikasi insektisida di wilayah Modoinding relatif sama. Petani sayur diwilayah Modoinding mengaplikasikan insektisida untuk kubis dan tomat 4-6 kali dalam satu musim tanam. Penetapan kadar residu insektisida untuk kubis dan tomat, juga dilakukan di wilayah Rurukan. Berdasarkan data padatabel14, nampak kadar residui nsektisida profenofos yang ditemukan pada kubis,lebih inggi dibandingkan dengan yang adaditomat. Hal ini disebabkan perbedaan frekwensi aplikasi insektisda untuk kedua tanaman ini. Petani di wilayah Rurukan mengaplikasikan insektisida 6-8 kali untuk tanaman kubis dalam satu kal imusim tanam, sedangkan untuk tanaman tomat, petani mengaplikasikan insektisida 4-5 kali. Sesuai keputusan bersama menteri kesehatan dan menteri pertanian No: 881/MENKES/SKB/III/1996,tentang batas 
maksimum residu (BMR) pada hasil pertanian, dinyatakan bahwa BMR profenofos untuk produkdagingadalah $0,05 \mathrm{mg} / \mathrm{Kg}$ atau $0,05 \mathrm{ppm}$. Sampai saat ini belum ada penetapan pemerintah untuk BMR profenofos pada produk sayuran. Jika angka penetapan BMR untuk produk dagang, dijadikan pembanding untuk menginterpretasikan data yang ada pada tabel 3 dan 4, maka kadar residu profenofos pada kubis dan tomat di Modoinding dan Rurukan tergolong tinggi. Selain itujuga kadar residu yang ditemukan pada kubis dan tomat di Modoinding dan Rurukan , sangat tinggi atau jauh melebihi nilai Acceptable DailyIntake (ADI) dari profenofos yang hanya sejumlah $0-0,1 \mathrm{mg} / \mathrm{Kg}$. Berdasarkan nilai $A D I$ maka dapat diperhutungkan untuk konsumsi pangan dengan berat badan berkisar $70 \mathrm{Kg}$,maka maksimum residu profenofos yang masih di tolrtoleransi ditoleransi untuk masuk ke dalam tubuh hanya $0,7 \mathrm{mg} / \mathrm{hari}$.

\section{KESIMPULAN}

Petani sayuran di wilayah Modoinding dan Rurukan mengaplikasikan insektisida golongan organofosfat dan piretroid pada tanaman kubis dan tomat.

Jenis residu insektisida pada kubis dan tomat di Modoinding dan Rurukan yaitu profenofos. Kadar residu profenofos tertinggi pada kubis dan tomat, di kedua wilayah ini, jauh melebihi nilai ADI dari profenos

\section{DAFTAR PUSTAKA}

Association of Official Analytical Chemist. Washington.

Djojosumarto. 2010. Teknik Aplikasi Pestisida Pada Tanaman. Kanisius. Yogyakarta

Hadi,S. 1991. Pestisida Dan Cara Aplikasinya Insektisida. Badan Kerjasama Perguruan Tinggi Negeri Se-Indonesia Timur. Ujungpandang

Hoesain, M. 2005. Penggunaan Pestisida Di Lingkungan Agroekosistem dan Dampaknya Bagi Kesehatan Lingkungan. Universitas Airlangga . Surabaya.

MAPPOM. 1990. Identifikasi Dan Penetapan Kadar Residu Insektisida Golongan Organofosfat Pada Sayuran. Metode Analisis Pusat Pengujian Obat dan Makanan Nasional. Badan POM. Jakarta.

Pandit , I. G. 2006. Resiko Pestisida

Pertanian. Kanisius.

Yogyakarta Sudarmo.1989.

Pestisida Tanaman.

Kanisius . Yogyakarta. 